\title{
The Role of the Judiciary in the Promotion of Democracy and Human Rights in Cameroon
}

\author{
Avitus Agbor \\ School of Undergraduate Studies, Faculty of Law, North-West University, \\ Mafikeng Campus, Mmabato, North-West Province, South Africa \\ aagbor@gmail.com
}

\begin{abstract}
The ratification and domestication of international human rights instruments could be used as indices to determine a state's commitment to the promotion and protection of, and respect for, human rights. Within municipal legal systems, the judiciary is one of the stakeholders to fulfil these tasks. As one of the organs of government, it can play a critical role in defining the content and evolution of both democracy and human rights. Even though a state party to numerous international human rights instruments, a critical analysis of Cameroon's institutional mechanisms reveals that there is a conspicuous incompatibility between these institutional mechanisms and the ideals of democracy and human rights. More specifically, the power of the judiciary, as stipulated in the Constitution, is very limited. This parochial mandate has had a heavy toll on first, the democratic evolution of the country; and secondly, on ensuring the promotion, protection of, and respect for, human rights. This paper argues that the judiciary in Cameroon should play a role in enhancing democracy and human rights. To do this, the judiciary must undergo a paradigm shift from a complacent and disturbing judicial inertia to judicial activism.
\end{abstract}

\section{Keywords}

Constitution of Cameroon - democracy - human rights - judiciary - political rights rule of law 
For a country whose path to democratization has been described as being in 'a state of suspended animation,, ${ }^{1}$ it is necessary to consider (and even interrogate) what institutions are in place to ensure that the democratization process is thorough, genuine and progressive. Despite its ratification of numerous human rights instruments that highlight both the role of the judiciary in the protection of human rights and advancement of democracy, the judiciary of Cameroon has not regained its appropriate position in ensuring that it advances democracy and human rights in the country.

Even though Cameroon's Constitution has suffered numerous amendments over the decades, the 1996 Constitution was a radical departure from earlier versions of the Constitution as it gave recognition to fundamental rights and freedoms. ${ }^{2}$ The Constitution affirms its support for the contents of the core international human rights instruments, especially the principles enshrined in them. It blends civil, political, economic, social and cultural rights. Stipulated in the Preamble, constitutional recognition of the fundamental rights and freedoms signalled a significant and colossal stride in the domestication of international human rights. In addition to these rights, the Constitution stipulated the democratic character of the Republic, with emphasis that it will 'protect traditional values that conform to democratic principles, human rights and the law. ${ }^{3}$ In addition, a closer look at the phraseology of the Preamble reveals that the country is not limited to the rights expressed therein. It states as follows ' $[\mathrm{w}] \mathrm{e}$, people of Cameroon ...' do

[a]ffirm our attachment to the fundamental freedoms enshrined in the Universal Declaration of Human Rights, the Charter of the United Nations and The African Charter on Human and Peoples' Rights, and all duly ratified international conventions relating thereto, in particular, to the following principles....

Therefore, despite the compendious and skeletal articulation of a few rights in the Preamble to the Constitution, there is a firm attachment to the fundamental freedoms enshrined in the United Nations' Universal Declaration of Human

1 J.-G. Gros, 'Preface' in J.-G. Gros (ed.), Cameroon: Politics and Society in Critical Perspectives (Lanham, MD: University Press of America, 2003), at p. 22.

2 See the Preamble to the 1996 Constitution of Cameroon.

3 Article 1(2) of the Constitution.

4 Emphasis added. 
Rights (hereafter referred to as the UDHR ), ${ }^{5}$ the Charter of the United Nations, ${ }^{6}$ the African Charter of Human and Peoples' Rights (hereafter referred to as the ACHPR,${ }^{7}$ as well as all duly ratified international conventions relating to these freedoms and rights. By virtue of the Constitution, such ratified international agreements constitute a source of law in Cameroon. ${ }^{8}$ In addition, they enjoy a supremacy over every domestic law in the event that there is a conflict. ${ }^{9}$ They are self-executing.

A Synoptic Analysis of Democracy, Human Rights and the Rule of Law

As discussed above, the concepts of democracy, human rights and rule of law remain the basic pillars of any democratic society. In all these three concepts, the judiciary has a crucial role to play. In the absence of any of these, the democratic content of that society becomes questionable. These three concepts, as discussed below, have a relationship with each other. In fact, they have some degree of interdependence which have been recognised by some international instruments. They constitute the three inseparable pillars of a progressive and stable democracy.

\subsection{Democracy and Human Rights (Core Civil and Political Rights)}

Democracy and human rights share a mutually inclusive relationship as there can be no human rights without democracy and vice-versa. The existence of this relationship is not new: it is expressly stipulated in numerous international human rights instruments. The UDHR provides that 'everyone has the right to take part in the government of his country, directly or through freely chosen representatives.' ${ }^{10}$ It further stipulates that equal access to public service in one's country is a right, ${ }^{11}$ adding that

5 Universal Declaration of Human Rights, United Nations General Assembly Resolution 217A, U.N.G.A. 3rd Session, U.N. Doc. A/Res/3/217A (1948) of 10 December 1948.

6 United Nations, Charter of the United Nations, 24 October 1945, 1 U.N.T.S. XVI, available online at: http://www.unwebsite.com/charter (accessed 8 June 2014).

7 African Charter on Human and Peoples' Rights, 27 June 1981, OAU Doc. CAB/LEG/67/3 rev. 5; 1520 U.N.T.S. 217. It was adopted on 27 June 1981 and entered into force on 21 October 1986.

8 Article 45 of the Cameroon Constitution.

$9 \quad$ Ibid.

10 Article 21(1) of the UDHR.

11 Article 21(2) of the UDHR. 
the will of the people shall be the basis of the authority of government; this will shall be expressed in periodic and genuine elections which shall be by universal and equal suffrage and shall be held by secret vote or by equivalent free voting procedures. ${ }^{12}$

This relationship resurfaces again in the International Covenant on Civil and Political Rights (hereinafter referred to as the ICCPR), ${ }^{13}$ wherein it is provided that every citizen shall have the right and the opportunity 'to take part in the conduct of public affairs, directly or through freely chosen representatives.'.14 In addition, it makes mention of the right to 'vote and to be selected at genuine periodic elections which shall be by universal and equal suffrage and shall be held by secret ballot, guaranteeing the free expression of the will of the electors', ${ }^{15}$ and for everyone to have 'access, on general terms of equality, to public service in his country.'16 The ACH PR also recognises this relationship as it expressly states that 'every citizen shall have the right to participate freely in the government of his country, either directly or through freely chosen representatives in accordance with the provisions of the law.17 In addition to this, the ACHPR articulates the right of every citizen to equal access to public service of his country. ${ }^{18}$

This recognition of the link between democracy and human rights is not limited to the African continent. In addition to stipulating the relationship between democracy and human rights, different regional inter-governmental organisations have articulated these (democracy and human rights) as some of their primary goals. For example, the Inter-American Democratic Charter (hereafter referred to as the IADC), ${ }^{19}$ proclaimed by the General Assembly of the Organization of American States provides that the 'peoples of the Americas

12 Article 21(3) of the UDHR.

13 The International Covenant on Civil and Political Rights, 16 December, 1966, 999 U.N.T.S. 171.

14 Article 25(a) of the ICCPR.

15 Article 25(b) of the ICCPR.

16 Article 25(c) of the ICCPR.

17 Article 13(1) of the ACHPR.

18 Article 13(2) of the ACHPR. In addition to the ACHPR, the Constitutive Act of the African Union makes the promotion of democratic principles and institutions, popular participation and good governance, the promotion and protection of human and peoples' rights in accordance with the African Charter on Human and Peoples' Rights and other relevant instruments, inter alia, as some of its objectives.

19 Inter-American Democratic Charter, adopted by the General Assembly at its Special Session held in Lima, Peru, on September 11, 2001, OEA/Ser.G/CP-1. 
have a right to democracy and their governments have an obligation to promote and defend it.'20 It also affirms the relationship between democracy and human rights by stating that 'democracy is indispensable for the effective exercise of fundamental freedoms and human rights in their universality, indivisibility and interdependence, embodied in the respective institutions of states....21

These different instruments, both at global and regional levels, do provide eloquent evidence of the right to democratic governance across the world. ${ }^{22}$ The effect of the substantive contents of these instruments and the rights stipulated therein is another (new) legal entitlement in international law. ${ }^{23}$ These instruments provide not only a right to democratic governance, they also make it an indispensable condition for validating governance. This new legal entitlement has been created based in part on the customary practices of many states in the world and partly on the collective interpretation of treaties. ${ }^{24}$

It is difficult to talk of a democracy without some level of protection of human rights. Democracy is not possible without some level of protection of human rights. For example, people would not be in a position to participate in free elections unless they do enjoy certain minimum of fundamental civil and political rights such as the rights to life, security and liberty of the person, freedom of expression, participation in government, and political association. Respect for these rights, at a minimum, does create a fecund environment for meaningful or effective political participation and competition.

20 Article 1 of the IADC.

21 Article 7 of the IADC.

22 Thomas M. Franck calls it 'democratic entitlement', which he considers as becoming increasingly global, and can be promoted and protected by collective international process. T.M. Franck, 'The Emerging Right to Democratic Governance', 86 American Journal of International Law (1992), 46-91.

23 Franck argues that such democratic entitlement has been transformed from a moral prescription to an international obligation, with a gradual evolution that has witnessed an accelerated tendency in the past decades. Franck, supra note 22, at 47. A series of United Nations Resolutions passed by the Commission on Human Rights support this. Though not having the force of law, various resolutions made by the Commission on Human Rights reflects the evolution of this custom in international law. See Commission on Human Rights Resolution 2000/47 of 25 April 2000, on 'Promoting and Consolidating Democracy', Resolution 2001/36 of 23 April 2001, on 'Strengthening of Popular Participation, Equity, Social Justice and Non-Discrimination as Essential Foundations of Democracy', and Resolution 2002/46 of 23 April 2002, on 'Further Measures to Promote Democracy'.

24 Franck, supra note 22, at 47. Franck further contends that such a legal entitlement is becoming a requirement of international law, applicable to all and implemented through global standards, with the help of regional and international organizations. 
The contents, or most, of the ICCPR, are closely associated with the democratic process and are intrinsic to democratic governance especially the right to participate in public affairs. This right depends on the exercise of other rights (such as the rights to freedom of expression and freedom of association) and can only be effectively exercised if these few aforementioned civil and political rights are respected. Other rights related to the autonomy of agency and decision-making, including the right to freedom of thought and conscience and the right to privacy, are also relevant to the exercise of political rights.

Political rights are central in a true democracy. The respect for minority rights, the freedom of individual thoughts and the formation and dissemination of opinions without fear of being victimized, legal and political equality in state institutions and processes, are all incidental to democratic governance, which today, are universally considered to be core values. ${ }^{25}$ If these are perceived as universally important, any democracy worthy of the name must provide for processes and institutions that recognise these values, and more importantly, the relationship between democracy and human rights. Arguably, as a scholar opines, democracy itself is a universally desirable value. ${ }^{26}$

\subsection{Democracy and Rule of Law (Equality, Inclusion and Accountability)}

Just as there is a link between democracy and human rights, there is also a link between democracy and the rule of law. By practical definition, a democracy is a system that respects the rule of law. Democratic procedures and the human rights necessary for the functioning of democracy are written into enforceable laws. In effect, they do become the rulers or governors. Democratic societies are run or governed by laws, not individuals or passions. ${ }^{27}$ As the rule of law is part of human rights, respect for human rights by democracies also implies a respect for rule of law. ${ }^{28}$

25 F. Spagnoli, Homo Democraticus - On the Universality and the Not So Universal Possibility of Democracy and Human Rights (Cambridge: Cambridge Scholars Press, 2003).

26 Ibid., at p. 7. 'One of the greatest challenges to humankind in the new century will be the struggle to make the practice of democracy equally universal. In that struggle, nations in which democracy is already well established will need to be vigilant in preserving that achievement, and to work together to help those where democracy is still new or emerging'. United Nations Secretary-General, Kofi Annan, Press Release SG/sm/7467 of 27 June, 2000, on Warsaw Conference on 'Towards a Community of Democracies'.

27 On the other hand, undemocratic societies are governed by people and their passions.

28 A state may, however, respect the rule of law without being a democracy. The laws that are used to rule do not have to be democratic laws, need be framed by the people, and do not have to conform to human rights. For there to be rule of law, it is sufficient that the law rules, there is separation of powers, which actually guarantees and enforces respect for 
While each usually requires the other, the equations are not perfectly reversible. ${ }^{29} \mathrm{~A}$ state that respects the rule of law does not have to be a democracy, but it has the best chances of survival in a democracy. When the people frame the laws, it is more likely that the people will respect the laws and the laws rule when they are respected. Also, a democracy without a rule of law is not a democracy as it breeds avenues for inequality, manipulation and marginalization. Separation of powers and intermittent elections at local, state and national levels are insufficient to make a democracy. While there is always the risk that elections can be manipulated, fairness can be ensured only via the rule of law. Without the rule of law, enforceability of human rights becomes impossible. In effect, there will be no proper democracy.

In the absence of human rights, it is difficult to have a true democracy. Also, while elections make a democracy possible, they do not guarantee democracy. The rule of law and respect for the law, including the laws that protect human rights as necessary elements of elections, are also necessary conditions. The procedures by which power is granted, renewed or lost, are regulated by laws that have to be respected. The creation and manifestation of the will of the people, as well as the election of representatives of the people are guaranteed and protected by enforceable laws. The rule of law is a human right, and democracy cannot exist without rule of law.

However, a democracy requires more than the legal protection of rules and rights necessary for the creation and expression of the will of the people. After power is granted on the basis of the expression of the will of the people, it is incumbent on those in power to implement the will of the people. ${ }^{30}$ The way in which this will can be implemented (in other words, the exercise of power) is also regulated by laws. It is not because power comes from the people that this power is always beneficial: such powers must be limited by principles of the rule of law and human rights just as any other kind of power. The fact that power comes from society makes it all the more important to stress the

the law. The origins and content of the laws remain irrelevant for the rule of law, but not for democracy and human rights.

29 A good example is the presence of the rule of law without democracy and human rights. But democracy cannot thrive without human rights and rule of law, human rights cannot succeed without democracy and rule of law. And the rule of law must be present to give legal meaning and effectiveness to democracy and human rights.

$30 \quad$ See note 23 . 
difference between state and society, and this difference can only emanate from the rule of law. ${ }^{31}$

\subsection{Relationship between Rule of Law and Human Rights}

Human rights and the rule of law are inter-connected. This inter-connection is reflected in some instruments establishing intergovernmental organisations. For example, the Constitutive Act of the African Union expresses the determination of the States Parties 'to promote and protect human and peoples' rights, consolidate democratic institutions and culture, and to ensure good

31 A broad and minimal definition of the rule of law does not contain human rights. Neither does it imply the concepts of democracy nor justice. It maintains neutrality when it comes to values: A.O. Okoye, 'The Rule of Law and Sociopolitical Dynamics in Africa', in P. Tiyambe Zeleza and P.J. McConnaughay (eds), Human Rights, The Rule of Law, and Development in Africa (Philadelphia, PA: University of Pennsylvania Press, 2004), chapter 4, at p. 72. See also L. Mbunda, 'Securing Human Rights Through the Rule of Law in Tanzania' in P. Tiyambe Zeleza and P.J. McConnaughay (eds) Human Rights, The Rule of Law, and Development in Africa (Philadelphia, PA: University of Pennsylvania Press, 2004), pp. 144-156. However, the rule of law is considered on one hand, to mean the enforcement of laws which have been adopted according to a prefixed process, promulgated publicly, are not retroactive in application, are stable, clear, unambiguous, systematized on the basis of substantial generalization, and are applied by independent courts in a consistent way and according to procedural rules. Dimitrina Petrova considers the rule of law an important component of the definition of democracy. See D. Petrova, 'Strengthening the Rule of Law in Building Democratic Societies: Human Rights in the Administration of Justice' (Geneva: Office of the High Commissioner for Human Rights, United Nations, Seminar on the Interdependence Between Democracy and Human Rights, 25-26 November 2002). See also Spagnoli, supra note $5^{2}$, at pp. $5^{8-59}$. It is easy to hear politicians and statesmen herald their states as deeply dependent on the rule of law, in order to justify their modernity and commitment to the supremacy of law over individuals. Nonetheless, there are standard institutions and mechanisms that must be present in a society that claims to be dependent on rule of law. Such standard institutions and mechanisms (procedural) include, but are not limited to, judicial independence, accessibility to justice especially for excluded groups, promulgation of laws following predefined processes and by competent authorities, judicial review, due process in criminal procedure, constitutionalism (the existence of separation of powers with checks and balances), supremacy of the law over individuals (equality of all before the law), non-retroactivity of the law (non-application of ex post facto laws), a vibrant civil society, a virile Bar, control of military personnel by civilian authorities and intolerance to impunity by bringing to account perpetrators of legal wrongs before the competent bodies and subjecting them to administrative and or judicial proceedings as the unavoidable consequence(s) of their unlawful act(s) or omission(s). 
governance and the rule of law. ${ }^{32}$ It further stipulates that the 'respect for democratic principles, human rights, the rule of law and good governance' remain the foundational principles of the Union. ${ }^{33}$ These reflect the importance of the rule of law as an institution for nurturing and retaining democracy as a political culture that enhances the respect, promotion and protection of human rights. The question is whether it is feasible, without the rule of law, to enhance the respect for, and promotion of, human rights.

There exist two different (though complementary) functions of law, which are fulfilled in regard to patterns of domination. ${ }^{34}$ On one hand, law is one of the forms in which such domination is not only established, but also maintained. On the other hand, law reproduces the limits to domination. It is used as the legitimate form for both processes in modern governments, notably in autocratic and transitional societies. The system of legal norms, in legitimizing the dominant status of the stronger groups also protects the weak. In this second function, law ensures that domination is not absolute and entirely arbitrary. ${ }^{35}$

Human rights are mostly claimed by aggrieved parties. These include the rights and interests of others, including those of society as a whole, which, often, stand in the way. There is therefore the need for someone to exercise judgment in weighing certain rights against others and the interests of the public. Human rights generate new laws. Despite their articulation in the law, an individual can access them as legal rights only by turning to a court of law. Adjudication of such rights involves the weighing of certain rights against others by judicial, administrative or alternative bodies because, to hold that a right has been violated, the court, in its judgment, must first consider the defendant's offence or behaviour and establish to what extent the defendant acted in legitimate exercise of his or her own rights and interests. The rule of law is thus an indispensable condition for the protection of human rights. ${ }^{36}$

32 Preamble to the Constitutive Act of the African Union.

33 Article $4(\mathrm{~m})$ of the Constitutive Act of the African Union. See also Article I-2 of the Constitution of Europe, which makes respect for the rule of law and human rights one of the foundational values of the European Union.

34 Domination here refers to the 'phenomenon of a certain degree of control by some individuals over the life choices of others.' Petrova, supra note 31.

35 Ibid. The legal defence and promotion of human rights fulfils this second protective function of the law in society.

36 S. Ghutto, 'The Rule of Law, Human and Peoples' Rights and Compliance with Regional and International Agreements and Standards by African States' (African Forum for Envisioning Africa, Nairobi, Kenya, 26-29 April 2002). 
Effective protection of human rights requires a strong legal culture, which provides procedural venues for allocating responsibility for human rights violations. In such a strong legal culture, people perceive events and realities with a typical legal mind, considering every act and omission as a potential legal dispute that is actionable in the courts. That the rule of law is indispensable in the enhancing the respect and promotion of human rights in any democratic society is now a settled fact.

From the above discussion on the notions of democracy, rule of law and human rights, one can confidently posit the following: first, the ultimate goal of a democracy is the enjoyment of all human rights and freedoms; secondly, that the success of a democracy is for the most part, measured by the achievement of a high level of human rights promotion and protection; and thirdly, that the rule of law is indispensable for the respect and protection of human rights.

\subsection{Democracy, Human Rights and Judicial Power: The Link}

The role of the judiciary in the protection of human rights is very important. Even in systems where the judges appear to be very weak against governments and parliaments, judges play a vital role to the effective protection of human rights for a few reasons. First, there seems to be a global tendency of constitutional control of legislation, which, in the area of human rights, has been influenced by the development of the international human rights regime. Furthermore, judges are bound to interpret norms that are absolutely unequivocal. This, in effect, approximates law-making to the judiciary. However, there remains a distinction between a legal provision and a court decision. This distinction may, nonetheless, be less essential in the case of court decisions related to human rights. Therefore, the decisions of courts in human rights cases are of tremendous significance in its jurisprudence and evolution as they make a difference between a right, a right defended, and a right denied. In summation, they determine the justiciability of a right.

\section{Promoting Democracy via the Judiciary in Cameroon}

\subsection{Judicial Power in Democratic Societies: A Synoptic Discussion}

There are specific attributes that must be found in a democratic society. One of these is the presence of an accountability mechanism whereby public officials are held accountable by, and answerable to, the public for both their actions and decisions. This ensures that public officials are constantly watched in order to avoid bad governance or instances of abuse of power. This necessitates a 
separation of powers between the main organs of government. In a constitutional democracy, the concept of separation of powers permits and fosters dialogue between the three branches of government in order to achieve the goals stipulated in the Constitution. ${ }^{37}$

As such, the judiciary, as the organ empowered to interpret and apply the law, can determine whether the legislature and executive are performing their duties as spelt out in the Constitution. Judicial power connotes the authority vested in the courts to declare and interpret the law. In democratic societies, this power is used as an enforcement mechanism of the peoples' rights because the courts can be called upon at any time, by any individual, to adjudicate on the legality of an act: in fact, judicial power can be utilised by a people to seize the judiciary to rule on whether an executive or legislative act is compatible with the Constitution. In short, the judiciary is inadvertently translated to an agent of human rights enforcement by ensuring that the contents of human rights instruments, applicable in that country, are used as sources of law in the settlement of human rights disputes in particular, and other disputes in general. The judiciary should use this power vested in it by the supreme law of the land to sanction instances of executive and legislative excesses which negatively impact the rights of a people, which, in turn, would positively enhance the core civil and political rights contained in international instruments.

Given this role, the judiciary plays a great role towards advancing human rights and democracy in a country. ${ }^{38}$ The judiciary comprises judges appointed to the Bench by the relevant authorities. It includes even judges of the higher courts such as the Supreme Court and Constitutional Council. However, the Supreme Court has a much broader jurisdiction when compared to the Constitutional Council. It has specific matters it can entertain on appeal. On the other hand, the Constitutional Council is the sole judicial body with original jurisdiction when it comes to matters pertaining to the Constitution. However, on other matters spelt out in Article 47, the Constitutional Council is empowered to give 'a final ruling'. These two specific courts are the platforms upon which the legality of laws and constitutionality of legislative and executive actions can be challenged. Judges of these higher courts do therefore occupy a special position in Cameroon's democratic context and legal system. This is as a result of the fact that decisions of lower courts can be appealed

37 N. Barber, 'Prelude to the Separation of Powers', 6o Cambridge Law Journal (2001), 59-88, at 71; P. Kurland, 'The Rise and Fall of the Doctrine of Separation of Powers', 85 Michigan Law Review (1986), 592-613, at 603 .

38 See B.K. Twinomugisha, 'The role of the judiciary in the promotion of democracy in Uganda', 9 African Human Rights Law Journal (2000), 1-22, at 7. 
against in these higher courts. In addition, specific issues related to political rights, such as the settlement of regional and council electoral disputes, shall be determined by the administrative bench of the Supreme Court. ${ }^{39}$

Evidently, lacking judicial independence, the judiciary's role is spelt out in the Constitution. However, the Constitution itself is a law that must be applied in Cameroon. As such, the interpretation of the law must include the Constitution: including the values set forth therein. Some of these values are human rights, a democratic and secular state. ${ }^{40}$ The power of the judiciary therefore emanates from the Constitution itself, and as such, the judiciary must summon the courage to act 'as a bastion in the defence of the people against oppressive and unjust laws and practices.'41 More importantly, the fulfilment of this role becomes urgent when such laws and practices run contrary to the letter of the law and spirit of the Constitution.

The substantive content of international human rights is found in numerous human rights instruments, to most of which Cameroon is a state party. Therefore, such treaties constitute a source of law in Cameroon..$^{42}$ In addition, treaties ratified by Cameroon have a supreme status over every domestic legislation. ${ }^{43}$ Judges are empowered to apply the law, inclusive of international treaties ratified by Cameroon. Therefore, the core content of international human rights law, evidenced by the ratification history, constitutes a source of law in Cameroon, and should be applied by the judges. The judiciary should therefore protect the fundamental rights and freedoms contained in these instruments. By giving judicial recognition to these rights, it becomes clear that political rights would be justiciable, and executive actions that are repugnant to any law would be declared unlawful. Judicial protection of human rights is a cornerstone of a democratic society, and the judiciary of Cameroon must give judicial recognition to civil and political rights. These rights are justiciable, and only a constitutionally empowered authority like the judiciary can be summoned to regulate and restrain the executive and legislature from encroaching in any of these rights.

Human rights are the cornerstones of any democratic society. However, it is not the stipulation of these rights that is important: there must be a forum for victims or aggrieved persons to litigate violations. That is where the courts come in: the venue where victims or aggrieved persons can bring legal actions

39 Article 40 of the Constitution.

40 See the Preamble to the Constitution.

41 Twinomugisha, supra note 38 , at 7.

42 Article 45 of the Constitution.

43 Ibid. 
against the alleged perpetrators. The power of the courts to interpret the law, inclusive of international law, itself gives the judiciary the jurisdiction to handle human rights disputes. The justiciability of human rights within a court system is important given the fact that the executive and legislature would know that instances of unlawful, unjust, unfair or excessive conduct that violates a right, is incompatible with the Constitution or irreconcilable with any constitutional value (human rights and a democratic society) shall be declared avoided by the courts. The courts, as expected in any democratic society, should be very active in keeping the government faithful to the ideals and goals of democracy. ${ }^{44}$

In doing this, the courts provide redress and relief to victims of unlawful acts. In addition, they play an invaluable role in securing a better society for all - a society wherein human rights and democratic values are entrenched in social and political discourse and actions of both public and private officials. In addition, the judiciary will be keeping everyone faithful to the ideals of the country. As one scholar observes correctly, independence of the judiciary calls for innovation on the part of the judges, who 'should not wait for each and everything to be delivered to them in the form of laws and by-laws. They require imagination in the process of dispensing justice. 45

Cameroonian judges should be competent to embrace the concept of judicial activism. This requires moving away from the antiquated and out-dated practice of defining their role technically and narrowly. They should interpret the Constitution and other relevant human rights laws so as to promote justice, rule of law, democracy and human rights in the country.

\subsection{Judicial Independence in Cameroon}

Judicial independence is vital in the promotion of democracy, human rights and rule of law in any democratic society. ${ }^{46}$ It must be guaranteed by the Constitution, rather than oscillate according to whims and caprices of some individual(s). If guaranteed by the Constitution, then, the judges themselves would be called upon to adjudicate whenever there are instances of encroachment on its independence. In other words, the judiciary can, and should be, its very guarantor of independence, by construing strictly its power as stipulated in the Constitution and ensuring that such power is exercised without any interference. Such independence lies at the very heart of separation of powers, permitting the judiciary to pass judgments that may transcend political lines

\footnotetext{
44 Twinomugisha, supra note 38 , at 7.

45 C.M. Peter, Human Rights in Tanzania: Selected Cases and Materials (Cologne: Rüdiger Köppe, 1997), at p. 484.

46 Ibid.
} 
but contribute to a culture of democracy, rule of law and human rights. Judicial independence is a core democratic value. Instead of narrowing or limiting its power, the key political actors should consider it a vital tool for the enhancement of a democratic society. When such a role is performed, then, there will be no need to resort to extra-judicial means in the resolution of political disputes.

\subsection{Judicial Review and the Promotion of Democracy and Human Rights}

Judicial review, in legal parlance, refers to the power of the courts to rule on the legality (constitutionality) of an administrative act or law (irrespective of whether it is by the legislator or executive) or determine its compatibility with the basic principles of natural justice. It ensures that the acts of the various organs are not contrary to constitutional provisions. Judicial review gives the courts the power to listen to cases in which controversies as to the use and scope of power. It could be an administrative organ has acted ultra vires, or is unwilling to perform a mandated duty. This power is generally used by the courts to regulate the other organs of government, thereby ensuring some adherence to the stipulations contained in the fundamental laws of the country. In most countries, this power belongs to the highest courts with appellate jurisdiction. In the United States, the Supreme Court has this power.

In Cameroon, prior to 1996, the power of judicial review belonged to the Supreme Court. ${ }^{47}$ The judicial branch of the Supreme Court was responsible for hearing and adjudicating on matters that were related to the constitutionality of an act. Since the 1972 Constitution was amended, the Supreme Court was vacated from this power and handed to the Constitutional Council, which has original and final jurisdiction on issues related to the constitutionality of acts by the various administrative organs. ${ }^{48}$

But the most bizarre aspect of the power of judicial review is not its assignment to the Constitutional Council, but the fact that only defined persons can refer matters to it. The 1996 Constitution made it possible for a few persons to initiate litigation related to the constitutionality of an act. These include the President of the National Assembly, the President of the Senate, one-third of the members of the National Assembly or one-third of the Senators, as officers who can refer a matter to the Constitutional Council for a ruling on its constitutionality. ${ }^{49}$ Ordinary citizens who may be aggrieved by the unconstitutional act of any public authority are incompetent to make referrals to the Constitutional Council. In short, ordinary citizens, the majority of whom

47 Article 67(4) of the Constitution.

48 Article 46 of the Constitution.

49 Article 47(2) and 47(3) of the Constitution. 
could be victims of unconstitutional and illegal acts, do lack standing before the Constitutional Council.

Ordinary courts in the legal system are ousted of the jurisdiction to review the legality and incompatibility of the acts of public officials. Judicial review is limited to the ruling on the constitutionality of laws by the Constitutional Council. ${ }^{50}$ It does not include the power of the courts or the Constitutional Council to command public officers or restrain them from performing a particular act. With the writs of mandamus and injunction, Anglo-Saxon courts for the most part have been able to order public authorities to perform their duties and also restrict them from engaging in acts that are not within their jurisdiction.

The absence of the judicial independence, the notion of constitutionalism that nurtures the doctrines of checks and balances, separation of powers, and judicial review are major constitutional lapses in Cameroon. The toll of all these is felt in the stagnation of its democracy, and the continued development of a culture of disrespect for human rights in Cameroon. If democracy, rule of law and human rights have to be made the cornerstones of Cameroon's democratic evolution, then, significant changes must be made to the Constitution. In addition, the judiciary must take a radical position, shifting from the complacent judicial inertia in which it has resided for so long, to judicial activism with a robust and holistic approach that embraces treaties as a source of law and proceed to apply them as such in the courts over which they preside.

The basic law upon which other laws in the country derive their validity and authority must be amended to provide for such doctrines. Judicial independence, separation of powers, checks and balances and judicial review are notions that are reflected in a constitution, one can discern their presence or absence by simply perusing the constitution and noting how the various organs operate and relate with each other. It will be an exercise in futility if a projection is made without recommending an amendment in the Constitution that will contain and satisfy such doctrinal requirements, for they are indispensable concepts that cannot be undermined or relegated to the posterior if one has to claim that the particular democracy implemented in the country offer a platform for the exercise, respect and adjudication of civil, political, economic, social and cultural rights of a people. In the absence of judicial independence, separation of powers, checks and balances and the power of judicial review, the rule of law is an empty shell, a camouflage to the entire world, and the notion of human rights is nothing but rhetoric. 
Inherent in the powers of the judiciary is the interpretation of the law. Performing this constitutionally mandated function requires judges to apply the law and their conscience only. The interpretation of the law requires more than a strict construction of the letter of the law as it is written: it means situating the letter of the law within a socio-economic and political context, and to develop the law as a social machinery that orchestrates socio-economic and political change. 'Law' in this context is inclusive of international law and domestic legislation. It includes the Constitution as well as other pieces of legislations enacted by the competent authorities. This interpretation of the law must be done in ways that advance constitutional aspirations, ideals and values of the country, amongst which are democracy and respect for human rights and fundamental freedoms. The mandate to interpret and apply the law comes with the power to regulate the actions and decisions of public officials when they encroach into the sphere of citizens' rights and liberties, or are inconsistent with any constitutional provision or repugnant with any of the values enshrined therein. Clearly, an offspring from this mandate to interpret and apply the law is the power of the courts to review a law, a decision or act of a government official in order to determine if such a decision or act conforms to the laws of the country. Judicial review becomes a democratic mechanism used to ensure that the sphere of individuals rights is not unjustifiably encroached into. The judiciary becomes the organ that reviews the lawfulness of such decisions and actions of government officials.

Through the power of judicial review, the judiciary performs the function of protecting and enforcing the applicable laws of the country. It also checks on administrative lapses and excesses as affected persons can challenge the acts of public officials in courts. In a constitutional democracy, courts play the role of an arbiter and final protectors of rights. In addition, they advance the democratic culture by ensuring that no one is above the law, and a forum is provided wherein abuse of power can be challenged. As courts are given the mandate to interpret and enforce laws, they can determine the validity of executive and legislative actions to ensure that these organs of government do not only operate within the contours of their constitutional mandate, but also contribute to the furtherance of the democratic ideals and aspirations stipulated in the Constitution. Clearly, the power of judicial review, inherently present in the constitutional mandate of judges, empowers and enables judges to play a leading and crucial role in ensuring that a democratic culture is developed and preserved. It does so by reviewing the legality of the decisions and actions of public officials, serving as the arbiter to settle disputes of every kind, and more importantly, regulating the abuse of public power. This power 
of judicial review does not only fit into Cameroon's democratic society but also plays a vital role in promoting and protecting human rights, democracy and rule of law.

In light of the Constitution, the courts must determine whether a decision or act of public official is concordant with the ideals of democracy, human rights and fundamental freedoms. In performing such a role, the courts adjudicate the dispute in question and provide the applicable remedies to the parties involved.

Surprisingly, the Constitution makes it possible for only selected authorities to challenge the constitutionality of a law. ${ }^{51}$ The forum where the constitutionality of an act or decision can be challenged is the Constitutional Council. Two issues arise here: first, the Constitution is a municipal legislation, and is very limited. As such, even if only specific authorities have the standing to challenge any unconstitutional act or decision in the Constitutional Council, that does not mean other persons are automatically precluded from such kinds of litigation. These specific persons or authorities have standing only when it comes to challenging any constitutional provision. Secondly, and construed broadly, judges are to interpret the law. Law in this context means every law applicable in the country. This definitely includes international human rights law. The argument here is simple and straightforward: even though the Constitution limits the persons with standing to challenge the constitutionality of an act or decision, a broader construction of the powers of judges leads to the conclusion that judges and the courts can apply international law, especially international human rights law containing substantive and procedural rights. The major international human rights instruments have been ratified by Cameroon. Therefore, judges have before them a rich array of international human rights instruments to be used in their adjudication of disputes. While the Constitution eliminates the possibility of the wider Cameroonian public from challenging the constitutionality of acts and decisions of public officials, international instruments comprising a source of law in Cameroon should be applied broadly and strictly by the judiciary so that instances of encroachment of peoples' rights resulting from abuse of power can be curtailed. The content of human rights in the Constitution is hopelessly skeletal. However, a good understanding of the Preamble to the Constitution leads to the conclusion that the list of rights stipulated in the Preamble is not exhaustive: the Constitution declares that it recognises the fundamental rights and freedoms contained in international instruments especially those enshrined therein. 
Even though tempting, it is wrong to conclude that the list of rights contained in the Preamble constitute the only core content of human rights in Cameroon.

\subsubsection{Constitutional Allocation of Powers to the Judiciary}

Clearly, and unarguably, any democratic society should have in place a system of accountability. ${ }^{52}$ This ensures that public office bearers such as political leaders, law-makers, electoral officers and other senior public officers, are held accountable and answerable to the public for the decisions they make. ${ }^{53}$

\subsubsection{International Law as Law in Cameroon}

Articles 43 to 45 (inclusive) of the 1996 Constitution detail the application of treaties and international agreements in Cameroon. ${ }^{54}$ Article 43 gives the President of the Republic the power to negotiate and ratify treaties and international agreements. ${ }^{55}$ Article 44 deals with cases where the provision of a treaty or an international agreement is unconstitutional. ${ }^{56}$ Article 45 addresses the applicability and supremacy of treaties and agreements. It states as follows:

Duly approved or ratified treaties and international agreements shall, following their publication, override national laws, provided the other party implements the said treaty or agreement.

Article 45, in effect, makes treaties and international agreements not just applicable, but also to acquire a supreme status over national laws. The supremacy enjoyed by treaties and international agreements is inferred from the phrase 'override national laws'. It is therefore logical to postulate that every ratified treaty and international agreement is applicable in Cameroon as a source of law. In addition, the provisions of such ratified treaties and international agreements enjoy a supreme status over and when in conflict with national laws.

Numerous instruments exist in international law that stipulate the content of human rights. Most of these have been ratified by Cameroon. Given the applicability of ratified human rights instruments in Cameroon, it is necessary to examine the content of rights as expressed in the Constitution. Cameroon as a sovereign state is a member of the international community of states. She is a member of the United Nations, whose Charter she adheres to. She was a mem-

$5^{2}$ Twinomugisha, supra note 38 , at 6 .

53 Ibid.

54 Law No. 96-o6 of 18 January 1996 to amend the Constitution of 2 June 1972.

55 See Article 43 of the Constitution.

56 See Article 44 of the Constitution. 
ber of the defunct Organisation of African Unity (OAU), and is a member of the successor organisation, the African Union. As such, the relevant international human rights instruments of these two inter-governmental Organisations have been signed and ratified by Cameroon.

Of particular attention is the fact that these human rights instruments impose upon states parties the obligation to undertake legislative and other measures to ensure that the contents of the treaty are made part of the domestic laws of the state party. States parties have different procedures in place for the domestication of international treaties. The domestication of a treaty requires legislative enactment to import the contents of such a treaty so that municipal courts can give effect to them.

Legislative measures undertaken by a State Party to a treaty are just a dimension of domestication of the contents of a treaty as well as the fulfilment of its international obligations. Given the fact the Constitution recognises international law as law, and it is accorded a supreme status over domestic legislation, judicial construction of these laws becomes very vital in enhancing democracy and human rights in Cameroon. By interpreting these human rights treaties, the judiciary gives effect to the content of these substantive rights which do have an effect on the democratic evolution and content of the country. With an understanding of the applicability of international law in Cameroon, and the function of the judiciary in the interpretation of laws and adjudication of disputes, it is important to consider what role the judiciary can play in enhancing democracy in Cameroon.

\subsection{Perceiving Electoral Participation as a Political Right}

Through the power of judicial review, the judiciary can foment the content of civil and political rights in Cameroon. This can be done through reviewing the regularity and conduct of every elections in which citizens participate in government.

Numerous municipal, parliamentary and presidential elections have taken place in Cameroon since 1992 (the very first elections in the advent of multiparty politics). The organisation of these elections ( from registration of voters, eligibility for the different positions, conduct of elections to the proclamation of results) has been subjected to plenty of criticisms most regarding fairness and transparency. Numerous legal battles have erupted from elections organised since 1992. Parties to such disputes have contested either the integrity of the entire process, the independence of the organising body, the transparency 
of the results, the investigation of suspected cases of fraud, etc. Unfortunately, electoral disputes in Cameroon are appraised as administrative issues, and therefore, settled as such. The Administrative Bench of the Supreme Court does not tackle them as issues arising out of human entitlements: in other words, they are not seen as transcending the core content of political rights. This approach affects the way they are handled: judicial remedies are unavailable to parties to such administrative disputes.

Political rights are expressed in different human rights instruments to which Cameroon is a state party. Amongst these are the ICCPR and the ACHPR. These rights, of course, as decided by international human rights bodies such as the Human Rights Committee and the African Commission on Human and Peoples' Rights, are very justiciable. The classification and treatment of electoral disputes, even when the integrity of the entire electoral process is questioned, itself, is a justiciable violation of the victims' political rights.

In such cases, the judiciary must summon the courage to give meaning to these political rights by enforcing them. First, such disputes must be seen as illegitimate or unauthorised transgression of citizens' political rights that are not limited to the right to choose leaders, but must be construed and expanded to include even the right to be chosen as a leader. Every electoral dispute ought to be interpreted in this light: does it have the effect of compromising a victim's right to political participation? If so, what remedies should be recommended to give effect to these rights and therefore, convey a message to the parties in dispute?

The role of the judiciary in handling such electoral disputes is important. The judiciary must not accept the classification of electoral disputes as administrative in character: they must see it as possible transgressions of political rights. The resolution of these disputes should require a holistic appraisal of the content of their political rights, and the judiciary should consider the importance of these entitlements in the democratic evolution of any society.

\subsection{Freedom of Association}

Another key political right is the right of freedom of association. The right of freedom of association makes it possible for everyone to associate with others of his or her choice. Such associations could be pure political, social, economic, cultural, or professional.

During the early days of the political metamorphosis in Cameroon, restrictions were placed on the right of freedom of association. In fact, associations with some political groups were severely sanctioned. A specific law was enacted to regulate such activities in Cameroon. ${ }^{57}$ 
With an understanding that everyone has the right to associate freely with others, the judiciary of Cameroon ought to construe the content of this right in the light of the relevant laws that were enacted by the executive. The judiciary, in the light of its unique and immense role it has to play in a constitutional democracy, when cases arise, is supposed to examine the provisions of this law in relation to the rights of everyone. Unfortunately, this has not been the approach. Rather than strike out such laws as undemocratic and repugnant to the spirit and letter of a constitutional democracy founded on respect for human rights, the judiciary became complicit by its unwillingness to do what was expected.

\subsection{The Right to Freedom of Expression}

Of common knowledge to academics of different disciplines is the fact that the right to freedom of expression means the freedom to speak freely without censorship. In addition, it is not limited to verbal speech: it extends to, and includes every act of seeking, receiving or imparting information or ideas in others, irrespective of the medium that is used. From the foregoing, it is evident that the right to free speech is three-dimensional: first, it covers the right to seek and obtain information or ideas; secondly, the right to receive information or ideas; and third; the right to impart information or ideas. ${ }^{58}$ All these three could be exercised through different media, including but not limited to oral, in writing, in print, Internet or even different forms of arts.

International law recognizes the right to freedom of expression. Different international human rights instruments at both global and regional levels have stipulated this right. The UDHR states that everyone has the 'right to freedom of opinion and expression', and this includes the 'freedom to hold opinions without interference and to seek, receive and impart information and ideas through any media and regardless of frontiers. ${ }^{59}$ The ICCPR also recognises the right to free speech. It stipulates that everyone 'shall have the right to hold opinions without interference' and the 'right to freedom of expression' which shall include 'the freedom to seek, receive and impart information and ideas

$5^{8}$ See, generally, L. Alexander, Is There a Right to Freedom of Expression? (Cambridge Studies in Philosophy and Law) (Cambridge: Cambridge University Press, 2005); L.C. Bollinger and G.R. Stone, Eternally Vigilant: Free Speech in the Modern Era (Chicago, IL: University of Chicago Press 2003); H. Bosmajian, Freedom Not to Speak (New York, NY: New York University Press, 1999); S. Braun, Democracy off Balance: Freedom of Expression and hate Propaganda Law in Canada (Toronto, on: University of Toronto Press, 2004).

59 UDHR, Article 19. Though not binding, the UDHR is considered evidence of customary international law. 
of all kinds, regardless of frontiers, either orally, in writing or in print, in the form of art, or through any other media of his choice' subject to the restrictions stipulated in Article 19(3).

\subsubsection{Regulating the Right to Freedom of Expression in Cameroon}

Despite its affirmation to the fundamental freedoms contained in international instruments to which Cameroon is a state party, domestic legislative pieces have in effect curtailed these freedoms. This raises serious questions on the country's path towards democratization given the fact that media for the expression of opinions (especially those hostile to the government) are seriously restricted. As would be seen later, the right to freedom of expression is neither enshrined by the country's laws nor exercised by the people. In reality, you get penalized for the opinions and information you hold and disseminate: this being greatly attributable to the series of laws that were enacted with the aim of subjecting the press to very tight scrutiny, hold individuals who violate such laws responsible and deter others from taking the same trajectory. Two such laws serve as eloquent evidence of the perilous nature of freedom of expression in Cameroon, as well as the misfortune that befalls any violator. The first is the Penal Code, which creates a series of offences. ${ }^{60}$ The second is the 1990 Law regulating Mass Communication in Cameroon, enacted at a time of volatile and turbulent political activities in Cameroon. ${ }^{61}$

Categorised under 'Felonies and Misdemeanours Against the State', Part IV, entitled 'Public Authority' contains a list of offences. The following are some excerpts of the Penal Code criminalising the exercise of the right of free speech:

\section{Section 152: Contempt}

(1): A contempt shall mean any defamation, abuse or threat conveyed by gesture, word or cry uttered in any place open to the public, or by any procedure intended to reach the public.

(2): The exceptions defined by section 306 shall be applicable to contempt. $^{62}$

6o The Penal Code contains the general principles of Cameroonian criminal law (Book One: Sections 1-101) and specific offences (Book Two: Sections 102-370). These are applicable across the entire country.

61 Law No. 90-052 of 19 December 1990 Relating to Freedom of Mass Communication, as amended by Law No. 96-04 of 4 January 1996 (to amend and supplement certain provisions of Law No. 90-052 of 19 December 1990 relating to freedom of mass communication).

62 Section 306 of the Penal Code contains exceptions to defamation. It states as follows: 'The following shall constitute no offence: 
(3): Prosecution shall be barred by the lapse of four months from commission of the offence or from the last step in preparation or prosecution.

\section{Section 153: Contempt of President and other Dignitaries}

(1): Whoever commits a contempt of the President of the Republic or of the Vice-President of the Republic, of any person exercising the whole or a part of prerogatives, or of any foreign Head of State shall be punished with imprisonment for from one to five years or with fine of from twenty thousand to twenty million francs or with both such imprisonment and fine.

(2): Whoever commits a contempt of any Head of Government, or of any foreign Minister of a foreign government, or of a diplomatic representative accredited to the Government of the Republic shall be punished with imprisonment for from six months to two years or with fine of from twenty thousand to twenty millions francs, or with both such imprisonment and fine.

(3): The truth of the defamatory matter may never be proved.

Section 154 (new): Law No. 90-61 of 19 December 1990: Contempt of Public Bodies and Public Servants

(1) Whoever commits a contempt

(a) Of any court, of the armed forces, or of any public body or public administration, or

(1) Speeches within any legislative assembly, and any report or other document printed by order of any such assembly;

(2) Faithful accounts without malice of the public sittings of any such assembly;

(3) Proceedings in court and the speeches made and documents produced in court;

(4) Faithful accounts without malice of all such proceedings and speeches, save only of a prosecution or action for defamation;

(5) Publication of any judgment or judicial order, including those passed in a prosecution or action for defamation;

(6) An official report without malice by a person lawfully appointed to conduct an enquiry to the extent that it is germane to the enquiry;

(7) Imputations without malice by a superior on his subordinate;

(8) Information on any person given without malice to a third party having an interest, personal or official, in receiving it, or having power to remedy an alleged injustice;

(9) Criticism of any work of art, entertainment or opinion shown or expressed in public, provided that such criticism be not an expression of personal animosity;

(10) Any work of a historical nature and without malice. 
(b) In relation to his office or position, of any member of the Government or of the National Assembly, or of any public servant shall be punished, unless, in the case of defamation, he proves the truth of the defamatory matter, with imprisonment for from three months to three years, or with fine of from one hundred thousand francs to two million francs or with both such imprisonment and fine.

(2) Whoever, whether in speech or in writing, intended for the public, incites to revolt against the Government or institutions of the Republic shall be punished with the penalties provided in subsection (1) above.

\section{Section 155: Where not Public}

Where any defamation, abuse or threat has been committed otherwise than publicly against any person defined by either of the last two foregoing sections, the punishment, whether of loss of liberty or of fine, shall be halved.

The above sections of Cameroon's Penal Code are self-explanatory as they are self-evident of the intrusiveness and heavy control exerted by the Executive, and the perils of free speech. Contempt is given a very broad definition: defamation, abuse or threat conveyed by gesture, word or cry uttered in any place open to the public, or by any procedure intended to reach the public. Interestingly, liability is strict: the truth of the defamatory matter may never be proved where such contempt is of the President, Vice-President, or any individual to whom such office is delegated to and exercising the prerogatives of the offices of President or Vice-President. The same applies to foreign minister of a government. On the other hand, the offence of contempt of public bodies as spelt out in Section 154(1)(a)-(b) contains an exonerating ground: in the case of defamation, a defendant may prove the truth of the defamatory matter.

In addition to the Penal Code, there was the Freedom of Mass Communication Law of 1990. ${ }^{63}$ In the wake of increasing demonstrations and strikes over the country, coupled with the demand for legalization of political parties, the National Assembly passed a series of laws in December 1990 concerning rights and liberties. Among these was the law relating to Freedom of Mass Communications, popularly known as the 'MC Law' ${ }^{64}$ The proponents of this law considered that it was not only revolutionary and designed to

\footnotetext{
63 Law No. 90/052 of 19 December 1990 Relating to Freedom of Mass Communication, amended by Law No. 96/04 of 4 January 1996.

64 Law No. 9o/052 of 19 December 1990.
} 
eradicate all restrictions, but also to control the activities of the media for a better, mature and responsible use of the freedom of expression in the delicate stages of a budding democracy.

The Law was enacted to give effect to the constitutional right to freedom of the press, which, as stated, should be exercised in accordance with the law. ${ }^{65}$ The law applies to all forms and means of mass communication, ${ }^{66}$ more specifically, 'to printing, bookselling, press organs, publishing houses, distribution agencies, bill-posting and to audio-visual communication establishments. ${ }^{\prime}{ }^{67} \mathrm{In}$ addition, it regulated the profession of the journalist which must be exercised in accordance with the law. ${ }^{68}$ It made it free for anyone to engage in printing and bookselling, ${ }^{69}$ and required that all printed matter intended 'to communicate opinions to the public' to bear the name and address of the printer. ${ }^{70}$ It defined a press organ as any 'newspaper, periodical, magazine or pamphlet intended to communicate opinions, ideas, thoughts, current or social events which is published at regular intervals. ${ }^{71}$ The only exceptions to this definition are publications 'of a scientific, artistic, cultural, technical or professional nature regardless of their publication intervals. ${ }^{72}$ It makes open and free to anyone who wants to engage in the publication of a press organ, ${ }^{73}$ and stipulates the procedures for the commencement and conduct of such an activity. ${ }^{74}$ It also imposed obligations on such persons as well as prescribed penalties for any violations. ${ }^{75}$

Considered to be the 'anthem on the freedom of expression, ${ }^{76}$ it did not really create a free media. The particularly prescriptive and hortatory stipulations contained in the 1996 Constitution did not provide a sound basis for the

65 Section 1 of Law No. 9o/052 of 19 December 1990.

66 Section 2(1) of Law No. 9o/052 of 19 December 1990.

67 Section 2(1) of Law No. 9o/052 of 19 December 1990.

68 Section 2(2) of Law No. 90/052 of 19 December 1990.

69 Section 3 of Law No. 9o/052 of 19 December 1990.

70 Section 4 of Law No. 9o/052 of 19 December 1990.

71 Section $5(1)$ of Law No. 90/052 of 19 December 1990.

72 Section $5(2)$ of Law No. 90/052 of 19 December 1990.

73 Section 6 of Law No. 9o/052 of 19 December 1990.

74 Sections 7-12 of Law No. 9o/052 of 19 December 1990.

75 See generally Sections 13-73 of Law No. 9o/052 of 19 December 1990 (both obligations and penalties).

76 C.M. Fombad, 'The Mass Media and Democratization in Africa: Lessons from Cameroon', in J.M. Mbaku and J.O. Ihonvbere (eds), The Transition to Democratic Governance in Africa: The Continuing Struggle (Westport, CT: Praeger, 2003), at p. 228. 
growth of an independent and efficient mass media. One writer articulates the consequence of this in the following words:

Cameroonian politicians and administrators, freed from any constitutional constraints, have continued to, with probably decreasing gusto, to tightly control and restrict the activities of the media. It can be argued that new freedoms merely opened the field of political activity and debate just enough to enable the remaining restrictions and inequalities in the system to be felt even more strongly. ${ }^{77}$

\subsection{Judicial Adjudication of (Civil and) Political Rights:Judicial Escapism and Complicity}

Inasmuch as it may be difficult to identify cases in which the judiciary has considered international law in determining the unlawfulness of encroachments, there is plenty of evidence in international human rights bodies that points to the fact that the judiciary has been complicit in the destruction of civil and political rights. This evidence comes in the form of delays and failures by the relevant courts to hear cases referred to them by the aggrieved victims. As a procedural requirement, every human rights body would require a complainant (or victim) to show that it has exhausted all domestic remedies, if any, unless they are duly prolonged, prior to a communication being considered admissible. ${ }^{78}$ The kinds of remedies required by such a procedure are of a judicial nature, and as the African Commission on Human and Peoples' Rights has emphasised over a number of cases, the importance of this rule is to give the defendant state the opportunity to be informed of these violations as well as find ways to redress them. ${ }^{79}$ As such, the relevant human rights body does

77 Ibid.

78 For example, see Article 56(5) of the ACHPR.

79 In Free Legal Assistance Group and Others v Zaire (2000) AHRLR 74-79, the African Commission highlighted the importance of this rule as follows:

The requirement of exhaustion of local remedies is founded on the principle that a government should have notice of a human rights violation in order to have the opportunity to remedy such violations before being called before an international body (Para 36).

See also Organisation Mondiale Contre la Torture and Others $v$ Rwanda (2000) AHRLR 282286 , para. 16 . This requirement of exhaustion of local remedies, if available, seems to have gained universal recognition by every human rights body, whether at the United Nations or some regional institution, As the African Commission held, this has now become a well-established rule of customary international law: see Institute for Human Rights and Development v Angola (2008) AHRLR 43-61, para. 38. 
not become a court of first instance. In numerous communications sent to the relevant human rights bodies (United Nations and African Commission), most of the victims succeeded in establishing that either no effective remedies were available or obtaining them was unduly prolonged. ${ }^{80}$ In most of these cases, the complaints were lodged at the Supreme Court of Cameroon. In consequence, the cases took a protracted turn, with numerous adjournments and rejections spanning over a period of five years. Most of these cases that fulfilled this procedural requirement were admitted and in the views of the relevant human rights body, the state was found to have violated the core civil and political rights. ${ }^{81}$

In cases like these, it is logical to argue that repeated adjournments and prolonged trials that run to up to five years depict an unwilling judiciary to perform its constitutionally mandated duties. In fact, it puts the judiciary as being complicit in the destruction of human rights.

\subsection{Challenges to the Exercise of Judicial Power in Cameroon}

Like in most democratic societies, the judiciary is only a branch of government. Its mandate is clearly spelled out in the Constitution: to administer the law. In practice, it is limited to this specific function: the administration of the law. Unfortunately, administering of the law covers just a miniscule of the entire legal machinery of a country. Some other authorities are empowered to enforce the laws. These authorities are provided the resources to ensure

$80 \quad$ On the other hand, the failure to exhaust local (domestic) remedies where they are available has resulted in communications being declared inadmissible by the Commission see the following cases: Legal Defence Centre $v$ The Gambia (2000) AHRLR 121-123, paras 15-18; Civil Liberties Organisation v Nigeria (2000) AHRLR 178, para. 2; Aturu v Nigeria (2000) AHRLR 179, para. 2; Academic Staff of Nigerian Universities $v$ Nigeria (2000) AH RLR 180, para. 2; International Pen (in respect of al-Jazouli) $v$ Sudan (2000) AHRLR 296, paras 3-4; Capitao v Tanzania (2000) AH RLR 313, para. 2; Buyingo v Uganda (2000) AHRLR 320, para. 3; Motale v Cameroon (2000) AHRLR 64-65, para. 19; International Pen (on behalf of Senn and Another) $v$ Côte d'Ivoire (2000) AHRLR 70, para. 2; Egyptian Organisation for Human Rights $v$ Egypt (2000) AHRLR 90-92, para. 15; Haye $v$ The Gambia (2000) AHRLR 102-103, para. 4; Dumbuya v The Gambia (2000) AHRLR 103-104, para. 2.

81 See generally the following Communications sent to the Human Rights Committee: Albert Womah Mukong v Cameroon, Communication Number 458/1991; Abdoulaye Mazou v Cameroon, Communication Number 630/1995; Fongum Gorji-Dinka $v$ Cameroon, Communication Number 1134/2002; Dorothy Kakem Titiahonjo v Cameroon, Communication Number 1186/2003; Philip Afuson Njaru v Cameroon, Communication Number 1353/2005; Pierre Désiré Engo v Cameroon, Communication Number 1397/2005; Ebenezer Derek Mbongo Akwanga v Cameroon, Communication Number 1813/2008; S.N.A. v Cameroon, Communication Number 1962/2010. 
that judgments are enforced, sentences that implemented, fines are paid, etc. These functions fall out of the scope of judicial power. This is a key limitation suffered by the judiciary: its very inability to enforce its own judgments. The legislative branch is empowered to enact laws, and could, per the prescribed procedures, amend a law in order to curtail the powers of the judiciary. The judiciary is thus very confined, whose very existence could be threatened by political actors if it is perceived as curtailing or intruding into their spheres of government. However, a democratic spirit requires that every citizen must invest his or her trust in the judicial system as the ultimate guarantor and protector of rights and the democratic evolution of a country, with the power and wisdom to define when specific limits are transcended, ensuring that public power is not abused.

In addition to this inability to enforce its own judgments, the judiciary is itself limited by legislative enactments that ouster its jurisdiction. Specific institutions have standing before the different forums where they can challenge the legality of certain acts. This ouster clause itself makes it impossible for the judiciary to entertain every complaint from individuals who are prohibited from pursuing such kinds of legal actions. As very few institutions are granted the locus standi to litigate on such issues, the exercise of judicial power is narrowed to such cases only.

\section{4}

\section{Conclusion}

The purpose of this paper was to highlight the role of the judiciary in the promotion of democracy and human rights in Cameroon. While democracy and human rights now reside as legal entitlements across the world, it is important to note that the core content of human rights and democracy has been expressly stated in numerous international instruments. Treaties of this nature have been ratified by Cameroon. Per the Constitution, ratified treaties automatically become law in Cameroon. In addition to that, such treaties enjoy a higher status over domestic laws. The judiciary, constitutionally mandated to administer the law, must adopt a much broader and liberal interpretation of the word 'law' to include even international law. In addition, judges must take a robust position by mainstreaming human rights in their judgments, especially in a democratic society wherein constitutionally recognised democratic values must be their guiding principles. This requires them to depart from the traditional complacency to judicial activism. In the words of one scholar, judges should take a conspicuous departure from strict adherence to precedent 'in favour of progressive and new social policies which are not always consistent 
with the restraint expected of appellate judges. ${ }^{82}$ In doing this, judges become agents of change in a socio-economic and political order: they give flesh and blood to the letter of the law when they apply it to factual situations without any constraint. In doing so, they do not only fulfil their mandate but also play a priceless role in taking democracy and human rights forward, preserving it as sacred and sacrosanct within that political order.

82 J.R. Nolan and J.M. Nolan-Haley (eds), Black's Law Dictionary (St. Paul, mN: West Publishing, 1990), at p. 847. 